\title{
Perbedaan Pendapat Pembelajaran Prabaca, Pratulis dan Prahitung Bagi Anak Usia Dini
}

\author{
MASNIPAL 1 , ARIF HAKIM2 \\ ${ }_{1,2}$ Program Studi Pendidikan Guru Pendidikan Anak Usia Dini, \\ Universitas Islam Bandung \\ Email: „masnipalmarhun@gmail.com, zarifhakim.spsupi@gmail.com
}

Article Received: 17-07-2018

Published Article: 06-11-2018

DOI: https://doi.org/10.29313/ga.v2i1.3855

\begin{abstract}
Today, differences of opinion about learning to read, write, and count for early childhood still occur by many parties. This study aims to obtain an overview of how the opinions and attitudes of principals and kindergarten teachers and $R A$ about reading, writing, and arithmetic learning. This research uses descriptive methods, and data collection is done through interviews and questionnaires. The results of the study indicate (1) the Education Office or Ministry of Religion does not require reading, writing, and arithmetic learning; (2) Most TK and RA carry out reading, writing, and numeracy learning and some others do not implement it; (3) the provision of reading, writing and counting activities in kindergarten and $R A$ is based on the request of parents of students; (4) reading, writing and counting activities in kindergarten and RA are conducted outside of school hours and are private;

(5) the implementation of reading, writing and counting activities in kindergarten and $R A$ is carried out by the teacher.
\end{abstract}

Keywords: Opinion, Reading, Writing, and Counting.

\begin{abstract}
Abstrak
Dewasa ini, perbedaan pendapat tentang pembelajaran membaca, menulis, dan berhitung bagi anak usia dini masih terjadi oleh banyak pihak. Penelitian ini bertujuan untuk memperoleh gambaran tentang bagaimana pendapat dan sikap kepala sekolah dan guru taman kanak-kanak dan Raudhatul Atfhal tentang pembelajaran baca, tulis, dan hitung. Penelitian ini menggunakan metode deskriptif, dan pengumpulan data dilakukan melalui wawancara dan kuesioner. Hasil penelitian menunjukkan (1) Dinas Pendidikan atau Kementrian Agama tidak mewajibkan pembelajaran baca, tulis, dan hitung; (2) Sebagian besar TK dan RA melaksanakan pembelajaran membaca, menulis, dan berhitung dan sebagian yang lain tidak melaksanakan; (3) pemberian kegiatan baca, tulis, dan hitung di TK dan RA lebih didasarkan atas pemintaan orangtua siswa; (4) kegiatan baca, tulis, dan hitung di TK dan RA dilaksanakan di luar jam pelajaran dan berbentuk privat; (5) pelaksanaan kegiatan baca, tulis, dan hitung di TK dan RA dilakukan oleh guru.
\end{abstract}

Kata Kunci: Pendapat, Prabaca, Pratulis, dan Prahitung

\section{Pendahuluan}

Sampai saat ini pembelajaran
permulaan membaca (Prabaca), menulis
(pratulis), berhitung (prahitung) masih
menjadi kontroversi (pro dan kontra) dalam
masyarakat di Indonesia, khususnya
dikalangan guru Paud, orangtua siswa Paud,
dan para pengelola atau penyelenggaraan
lembaga pendidikan anak usia dini, baik di
taman kanak-kanak (TK) di bawah Dinas

Pendidikan Kemendikbud ataupun raudhatul athfal (RA) di bawah Kementerian Agama.

Sejak lama pemerintah tetap konsisten melarang pemberian pembelajaran prabaca, pratulis, dan prahitung kepada anak usia dini meskipun untuk kelomplok B atau usia 6 tahun yang akan masuk sekolah dasar. Pemerintah tetap berpegang kepada pandangan tokoh pendidikan Indonesia Ki Hajar Dewantara yang beranggapan bahwa pembelajaran yang 
bersifat intelektualisme (membaca, menulis) tidak sesuai dengan azas taman kanak-kanak (Dewantara, 1977: 278); meskipun Ki Hajar Dewantara mengakui bahwa pendidikan taman Indria yang digagasnya mengadopsi konsep Montessori yang memasukkan academic materials dalam pendidikannya.

Taman Siswa boleh dibilang memakai kedua-duanya sebagai terkandung dalam sifat pendidikan Montessori dan Froebel itu, akan tetapi pelajaran panca indra dan permainan anak itu tidak terpisah, yaitu dianggap satu, sebab dalam Taman Indria hiduplah kepercayaaan, bahwa dalam segala tingkah laku dan segala keadaan hidupnya anak-anak itu sudah dihiasi oleh Sang Maha Among segala alat yang bersifat mendidik si anak (Dewantara, 1977:242).

Menyikapi larangan tersebut, baik para guru Paud, orangtua siswa Paud, para pengelola atau penyelenggara Paud memiliki pandangan dan sikap berbeda-beda. Sebagian besar orangtua menganggap penting prabaca, pratulis, dan prahitung diberikan kepada anak mereka terutama siswa kelompokk B sebagai persiapan memasuki sekolah dasar. Menurut mereka di sekolah dasar siswa yang telah memiliki kemampuan prabaca, pratulis, dan prahitung dianggap lebih cepat dalam menyesuaikan dengan pelajaran di sekolah yang berorientasi penguasaan akademik. Di samping itu, saat ini banyak sekolah dasar dalam seleksinya mengharuskan anak bisa baca, tulis, dan hitung sebagai salah satu syarat masuk. Para orangtua juga beralasan bahwa siswa yang belum bisa membaca, menulis, dan berhitung sangat sulit mengikuti pendidikan akademik di sekolah dasar, sebab guru tidak memiliki waktu cukup untuk membimbing prabaca, pratulis, dan prahitung karena harus menangani jumlah siswa lebih banyak yaitu 25 sampai 40 siswa dalam satu kelas.

Di kalangan para guru Paud, sikap tentang pembelajaran prabaca, pratulis, dan prahitung juga berbeda-beda. Ada guru yang sama sekali tidak memberikan atau memasukkan prabaca, pratulis, atau prahitung dalam pembelajaran dan hanya fokus kepada kegiatan bermain karena tidak dibolehkan pemerintah dan takut diketahui pengawas dari dinas pendidikan. Sebagian guru Paud secara sembunyi-sembunyi memberikan prabaca, pratulis, dan prahitung dengan alasan diminta oleh orangtua siswa dan jika tidak dilakukan takut sekolah mereka ditinggalkan siswa. Sebagian guru Paud yang lain secara terangterangan membelajarkan prabaca, pratulis, dan prahitung karena dianggap penting untuk persiapan siswa masuk sekolah dasar, meskipun dengan resiko mendapat teguran dinas pendidikan.

Sikap berbeda dalam pemberian prabaca, pratulis, dan prahitung juga terjadi di kalangan para pengelola atau penyelenggara lembaga Paud. Ada lembaga Paud yang melarang adanya prabaca. Pratulis, dan prahitung dan hanya kegiatan bermain; ada yang membolehkan sepanjang dilakukan dengan metodik yang tepat dan sesuai karakteristik perkembangan anak; ada lembaga yang sembunyi-sembunyi dan ada pula yang secara terang-terangan bahkan pembelajarannya semata-mata membaca, menulis, dan berhitung.

Kontroversi pembelajaran prabaca, Pratulis, dan prahitung di kalangan pendidikan anak usia dini telah berlangsung lama dan sampai saat ini belum ada titik temu memadai. Data tersebut diperkuat hasil berbagai pertemuan, diskusi, pelatihan- pelatihan dengan guru Paud atau RA di kota Bandung, Kabupaten Bandung, Kota Cimahi, dan kabaputen Cianjur yang menunjukkan belum adanya kesepakatan atau kesamaan pendapat terhadap perlu tidaknya pembelajaran prabaca, pratulis, dan prahitung.

Para tokoh Paud seperti Pestalozzi (1747-1827) sejak lama memasukan kegiatan menghitung (counting) dan mengukur (measuring) dalam pendidikannya, di samping belajar merasakan (feeling), dan menyentuh (touching). Montessori (1870-1952) juga memasukkan academic materials, yaitu pengajaran membaca, menulis, dan matematika dalam pendidikannya selain practical life dan sensory materials; walaupun sifatnya permulaan dan kelas dirancang kaya alat bantu serta sesuai kesiapan dan minat anak. Tokoh perkembangan anak seperti Havighurst (1972), mengklasifikasi tugastugas perkembangan awal masa kanak-kanak dengan mempersiapkan diri untuk membaca dan mengembangkan keterampilanketerampilan dasar untuk membaca, menulis, dan berhitung pada akhir masa kanak-kanak. Hurlock (1980) menyarakan agar pada awal masa kanak-kanak diberikan keterampilan pengusaan belajar berbicara, yaitu pengucapan, menambah kosa kata, dan belajar membentuk kalimat.

Saat ini kurikulum taman kanakkanak di Amerika juga mencakup aktivitas agar anak mempelajari pengalaman akademis, seperti baca-tulis dan membaca, matematika; di samping praktik yang 
sesuai perkembangan. Bahkan para ahli Paud di negara itu memberikan prioritas tinggi terhadap kemampuan baca-tulis anak (Morrison, 2008).

Yayasan Bersekolah Pada Ibu, yang didirikan tokoh-tokoh wanita Priangan tahun 1951; merupakan salah satu lembaga tertua di Indonesia yang menangani anak usia dini dan pendidikan gurunya, dan penggagas pendekatan belajar dengan sistem pusat minat/unit, memasukkan kegiatan membaca dan menulis permulaan dalam pendidikannya. Aktivitas pembelajaran dilakukan melalui alat permainan edukatif seperti kartu huruf, permainan angka. Kegiatan-kegiatan yang mengarah kepada prabaca, pranulis,dan prahitung dapat dilakukan sepanjang dengan bermain, anak suka dan senang. Contoh kegiatan pranulis misalnya menulis dengan telunjuk di udara, menulis di air, menulis di pasir; meremas dan memilin koran, dan mencorat-coret.

Guru Paud memiliki otoritas dalam pelaksanaan pembelajaran bagi anak usia dini, meskipun di bawah pembinaan kepala sekolah dan pengawasan dari pemerintah melalui dinas pendidikan. Sikap guru paud dalam pembelajaran termasuk pemberian atau tidak kegiatan prabaca, pratulis, dan prahitung juga banyak dipengaruhi oleh orangtua siswa. Tidak sedikit guru karena alasan permintaan orangtua siswa dengan sadar atau terpaksa memberikan prabaca, pratulis, dan prahitung.

Raudhatul Athfal (RA) merupakan bentuk layanan Paud jalur formal yang diselenggarakan oleh Kementrian Agama untuk masyarakat muslim. Keberadaan RA dijamin oleh UU No 20 Tahun 2003 tentang Sistem Pendidikan Nasional khususnya pasal 28 bahwa Paud jalus formal berbentuk TK, RA dan bentuk lain sederajat. Peran dan fungsi guru RA sama seperti guru Paud pada umumnya, kecuali pembelajaran yang dilaksanakannya berorientasi syariat Islam, seperti doa-doa, hafalan surah, kisah-kisah dan tokoh-tokoh Islam.

\section{Tinjauan Pustaka}

\section{Konsep dan Standar Nasional Paud}

Dalam kamus besar Bahasa Indonesia, membaca diartikan sebagai melihat serta memahami apa yang tertulis atau mengeja dan melafalkan. Membaca dapat pula diartikan sebagai suatu proses mengkontruksi arti antara tulisan dengan pengalaman yang diperoleh. Dengan demikian dalam membaca terkandung proses melihat tulisan, memprediksi artinya, dan mengintegrasikan informasi baru dengan pengalaman sebelumnya. Menulis diartikan membuat huruf atau angka dengan alat; mengarang atau membuat tulisan. Menulis melibatkan keaktifan tangan dan jari-jari untuk menggerakan alat tulis dalam membuat tulisan. Berhitung diartikan sebagai membilang (menjumlahkan, mengurangi, membagi, dan seterusnya). Berhitung lebih melibatkan kemampuan berpikir.

Dalam konteks pendidikan anak usia dini, kegiatan membaca, menulis, menyimak, dan berbicara merupakan ranah pengembangan aspek bahasa, meskipun juga melibatkan proses berpikir atau domain kognitif (Bromley, 1992 dalam Dhieni, 2008). Dalam kegiatan menulis, selain aspek bahasa juga aspek fisikmotorik, khususnya motorik halus yang melibatkan aktivitas jari dan tangan.

Dalam Permendiknas Nomor 137 Tahun 2014 tentang Standar Nasional Pendidikan Anak Usia Dini, lingkup pengembangan aspek bahasa untuk anak usia dini kelompok umur 5-6 tahun (usia kelompok RA) meliputi memahami bahasa, yaitu (a) mengerti beberapa perintah secara bersamaan, (b) mengulang kalimat yang lebih kompleks, (c) memahami aturan dalam suatu permainan, dan (d) senang dan menghargai bacaan; mengungkapkan bahasa, meliputi (a) menjawab pertanayaann yang lebih kompleks, (b) menyebutkan kelompok gambar yang memiliki bunyi sama, (c) berkomunikasi secara lisan, memiliki perbenndaharaan kata serta mengenal symbol-simbol untuk persiapan membaca, menulis, dan berhitung,

(d) menyusun kalimat sederhana dalam struktur lengkap (pokok kalimat-predikatketerangan), (e) memiliki mlebih banyak kata-kata untuk mengekspresikan ide pada orang lain, (f) melanjutkan sebagian cerita/ dongeng yang telah diperdengarkan, dan

(g) menunjukkan pemahaman konsepkonsep dalam buku cerita; dan keaksaraan, mencakup (a) menyebut sim,bol-simbol huruf yang dikenal, (b) mengenal suara huruf awal dari nama benda-benda yang ada disekitarnya, (c) menyebutkan kelompok gambar yang memiliki bunyi/huruf awal yang sama, (d) memahami hubungan antara bunyi dan bentuk huruf.

Dalam Standar Nasional Paud, aktivitas berhitung (membilang) terdapat dalam aspek 
kognitif khususnya berpikir simbolik, yaitu (a) menyebutkan lambang bilangan 1-10, (b) menggunakan lambing bilangan untuk menghitung, (c) mencocokkan bilangan dengan lambing bilangan, (d) mengenal berbagai macam lambing huruf vokal dan konsonan (aspek bahasa-membaca), (f) merepresentasikan berbagai macam benda dalam bentuk gambar atau tulisan (ada benda pensil yang diikuti tulisan) (aspek bahasa-menulis).

Prabaca, pratulis), dan prahitung melibatkan kegiatan-kegiatan seperti pengenalan huruf, pengenalan bunyi dan merangkai huruf-huruf dan kata dan pengenalan makna tulisan, menyebut, menggunakan, mencocokkan lambang bilangan, dan merepresentasikan dalam bentuk gambar atau tulisan.

\section{Pandangan Para Ahli}

Havighurst (1972), mengklasifikasi tugas-tugas perkembangan awal masa kanakkanak dengan mempersiapkan diri untuk membaca dan mengembangkan keterampilanketerampilan dasar untuk membaca, menulis, dan berhitung pada akhir masa kanak-kanak. Senada dengan pendapat Havighurst, Hurlock (1980) menyarankan agar pada awal masa kanak-kanak diberikan keterampilan pengusaan belajar berbicara, yaitu pengucapan, menambah kosa kata, dan belajar membentuk kalimat. Membaca menurut Hurlock (1980:124) sudah diperlihatkan anak pada awal masa kanakkanak, yaitu dengan melihat-lihat gambar dari buku, majalah, dan senang mendengar dongeng atau cerita- cerita hewan dalam kehidupan sehari-hari.

Pestalozzi (1747-1827), berpandangan bahwa cara terbaik dalam belajar bagi anak usia dini adalah memanipulasi pengalamanpengalaman anak, seperti belajar menghitung (counting), mengukur (measuring), merasakan (feeling), dan menyentuh (touching). Kegiatan menghitung dapat berupa banyak sedikit, besar-kecil; kegiatan mengukur misalnya tinggi-rendah, panjangpendek; kegiatan merasakan misal manispahit-asam-asin; kegiatan menyentuh misalnya halus-kasar, basah-kering, dan seterusnya.

Montes sori ( $1870-1952)$ , mengelompokkan aktivitas belajar dan bahan-bahan material pendidikan anak usia dini kedalam tiga kegiatan belajar, yaitu practical life atau pendidikan gerak; sensory materials untuk melatih indera; dan academic materials untuk pengajaran menulis dan membaca. Dalam kelompok practical life diajarkan empat latihan yang berbeda, yaitu merawat diri (contoh berpakaian, mengancing baju, memasang tali sepatu, mencuci tangan); merawat lingkungan (misal membersihkan meja, mengepel); hubungan sosial (contoh pelajaran sopan- santun, hormat menghormati); dan kontrol gerakan dan koordinasi (contoh berjalan, melompat, melatih keseimbangan, menuangkan benda dalam gelas).

Kelompok Sensory materials berisi aktivitas dan bahan-bahan untuk melatih penglihatan (seperti besar-kecil, tinggi rendah, panjang - pendek, ukuran); melatih pendengaran seperti kotak suara, membedakan bunyi bel); melatih perabaan (halus-kasar, padat-cair); melatih perasa/ lidah (manis-pahit-asin-asam); melatih pembauan.

Kelompok academic materials berupa bahan-bahan untuk mengajar menulis, membaca, dan matematika berupa kartu huruf, kartu angka, papan bilangan, termasuk kertas-pensil untuk kegiatan menulis. Dalam pendidikan Montessori, belajar membaca, menulis, dan berhitung sejak lama diberikan.

Yayasan Bersekolah Pada Ibu, yang didirikan tokoh-tokoh wanita Priangan tahun 1951; merupakan salah satu lembaga tertua di Indonesia yang menangani anak usia dini dan pendidikan gurunya, dan penggagas pendekatan belajar dengan Sistem Unit/ pusat minat. Sistem Unit pernah menjadi pilot projek seluruh Indonesia tahun 1963. Sistem Unit Yayasan Beribu memasukkan kegiatan membaca dan menulis permulaan dalam pendidikannya. Aktivitas pembelajaran dilakukan melalui alat permainan edukatif seperti kartu huruf, permainan angka. Kegiatan- kegiatan yang mengarah kepada prabaca, pranulis,dan prahitung dapat dilakukan sepanjang dengan bermain, anak suka dan senang. Kegiatan pranulis diawali menulis dengan telunjuk di udara, menulis di air, menulis di pasir; meremas dan memilin koran, dan mencorat-coret.

Kurikulum TK di Negara bagian Amerika. Para ahli Paud dan TK di negara bagian Amerika memberi prioritas tinggi terhadap kemampuan membaca, menulis, berbicara, dan mendengarkan. Berkaitan hal tersebut, Morrison (2012:260), menyatakan bahwa: 
Kurikulum TK tidak hanya mencakup aktivitas yang mendukung anak secara emosi dan sosial dalam belajar untuk menjadi seorang yang kompeten, tetapi juga mempelajari pengalaman akademis, seperti dalam baca-tulis, dan membaca, matematika, ilmu pengetahuan alam, ilmu sosial, dan seni. Namun semua pengalaman pertama-tama harus didekati dengan mempertimbangkan kemampuan dan keinginan anak usia dini lima dan enam tahun untuk bermain sambil belajar.

Masnipal (2013) dalam bukunya: "Siap Menjadi Guru dan Pengelola Paud Profesional" mengungkapkan bahwa kegiatan permulaan membaca, menulis, dan berhitung di taman kanak-kanak bagi anak usia 4-6 tahun bukan sesuatu yang perlu dikhawatirkan atau dilarang, jika mengikuti prinsip-prinsip pembelajaran yang benar, menarik, menyenangkan, dan bermakna bagi anak. Bermain harus menjadi corestone, menggunakan media/alat peraga yang tepat; guru berpengalaman; dan suasana menyenangkan.

\section{Tinjauan dari Perkembangan Anak}

Havighurst (1972), mengklasifikasi tugas-tugas perkembangan awal masa kanakkanak dengan mempersiapkan diri untuk membaca dan mengembangkan keterampilanketerampilan dasar untuk membaca, menulis, dan berhitung pada akhir masa kanak-kanak. Senada dengan pendapat Havighurst, Hurlock (1980) menyarankan agar pada awal masa kanak-kanak diberikan keterampilan pengusaan belajar berbicara, yaitu pengucapan, menambah kosa kata, dan belajar membentuk kalimat. Anak-anak juga diajak melihat gambar-gambar dan dibacakan cerita dari buku. Pada akhir masa kanakkanak bahkan guru dapat mengembangkan berbagai keterampilan dasar, seperti membaca, menulis, berhitung, dan pengembangan sikap. Membaca menurut Hurlock (1980:124) sudah diperlihatkan anak pada awal masa kanak-kanak, yaitu dengan melihat-lihat gambar dari buku, majalah, dan senang mendengar dongeng atau cerita-cerita hewan dalam kehidupan sehari-hari.

Peneliti telah mengobservasi selama 6 tahun terhadap perkembangan anak sendiri (2003-2009), telah dipublikasikan tahun 2013 dalam buku "Siap Menjadi Guru \& Pengelola Paud Profesional, bab III. Insting terhadap minat terhadap buku (membaca) dan menulis sebenarnya telah diawali anak pada umur 15 bulan, yaitu membalik-balikkan halaman buku dan munculnya kegemaran mencorat-coret dengan pensil/krayon. Pada umur 22 bulan, gemar corat-coret, pegang pensil dengan menggenggam. Sudah bisa menceritakan rangkaian gambar sederhana. Pada umur 27 bulan kemampuan anak dalam membaca dan menulis terus meningkat. Anak sudah bisa menceritakan hasil coratcoretannya dan membaca pura-pura dengan melihat gambar dalam buku. Pada usia 30 bulan, anak senang mendengar cerita-cerita dari buku bergambar yang dibaca ibunya. Umur 34 bulan, bisa mencerita isi gambar; tertarik bermain konstruktif (lego/lasy). Usia 3 tahun, anak berfantasi pura-pura baca yang ceritanya ia buat sendiri; gemar menggunting (pengembangan motorik halus menjadi dasar menulis). Pada usia 3,5 tahun, bisa menceritakan dengan benar cerita dalam buku bergambar, meskipun belum pernah diajarkan membaca. Usia 4 tahun, anak sudah bisa membaca sendiri tanpa bantuan, meskipun terbata-bata. Dari perkembangan tersebut, dapat disimpulkan bahwa keinginan atau minat anak terhadap kegiatan membaca dan menulis sudah muncul bahkan sebelum umur 5-6 tahun.

Dalam referensi lain menyebutkan bahwa membaca memiliki manfaat bagi anak usia dini dalam menyerap informasi dan pengetahuan yang dibutuhkan bagi kehidupannya. Durkin (dalam Dhieni, 2008) menyatakan tidak ada efek negatif pada anak-anak membaca dini, bahkan anakanak yang telah belajar membaca sebelum masuk sekolah dasar cenderung lebih maju di sekolah daripada yang belum pernah membaca dini. Salah satu keuntungan membaca menurut Sternberg (dalam Dhieni, 2008) bahwa belajar membaca akan memenuhi keingintahuan anak.

\section{Metode Penelitian}

Penelitian ini menggunakan metode deskriptif untuk menggambarkan bagaimana pendapat dan sikap kepala sekolah dan guru TK dan RA terhadap prokontra pembelajaran membaca, menulis dan berhitung kepada anak usia dini di sekolah mereka. Penelitian dekspritif memusatkan perhatian pada masalah aktual yang terjadi saat sekarang dan digambarkan sebagaimana adanya. Masalah yang akan diteliti akan dideskripsikan sebagaimana pengamatan lapangan. Penelitian dilakukan dengan langkah-langkah 
(1) perumusan masalah, (2) menentukan jenis data yang dibutuhkan, (3) menentukan teknik pengumpulan dan pengolahan data, dan (4) menarik kesimpulan.

Pertanyaan penelitian yang diajukan dalam rumusan masalah adalah bagaimana pendapat dan sikap kepala sekolah dan guru taman kanak-kanak dan Raudhatul Athfal tentang pembelajaran membaca, menulis, dan berhitung di tengah pro dan kontra dalam masyarakat. Alat pengumpul data menggunakan kuesioner. Pengolahan data dilakukan dengan cara memeriksa data, mengklasifikasi, tabulasi data dan membuat kategori, pemberian skor (skoring), penghitungan berdasarkan prosentase dan rata-rata (mean) serta menafsirkan data untuk membuat kesimpulan.

Penelitian ini dilakukan terhadap guruguru yang mengajar di TK/RA di tiga kecamatan, yaitu Kecamatan Cipanas Pacet, dan Sukaresmi Kabupaten Cianjur, dengan subjek berjumlah 80 orang. Permilihan guru TK/RA di tiga kecamatan Kabupaten Cianjur tersebut sebagai subjek penelitian didasarkan atas pertimbangan (a) karena faktor letak (jauh dekat dari kota) membuat pandangan dan sikap guru lebih bervariasi; kecamatan yang dekat dengan kota memperoleh informasi lebih cepat dan akurat, sedangkan yang jauh lebih lama dan kadang tidak sampai; dan (b) guru-guru yang dekat wilayah perkotaan lebih aktif berorganisasi, mengikuti seminar dan pelatihan sehingga mendapat informasi lebih banyak dan baru.

\section{Hasil Penelitian dan Pembahasan}

Penelitian ini mengajukan dua pertanyaan pokok, yaitu (1) bagaimanakah kebijakan Dinas Pendidikan dan Kementrian Agama Kecamatan Cipanas Pacet, dan Sukaresmi Kabupaten Cianjur tentang pembelajaran prabaca, pratulis, dan prahitung?; (2) Bagaimanakah pendapat dan sikap kepala sekolah dan guru Taman Kanak-Kanak (TK) dan Raufhatrul Athfal (RA) tentang pembelajaran pembelajaran prabaca, pratulis, dan prahitung?.

Untuk pertanyaan pertama, hasil olah data menunjukkan bahwa sebanyak 52,5\% responden menyatakan bahwa Dinas Pendidikan/Kementrian Agama Kecamatan Cipanas, Kecamatan Pacet, dan Sukaresmi Kab. Cianjur tidak mewajibkan guru memberi pembelajaran membaca, menulis, dan berhitung di TK dan RA. Dari jumlah tersebut, sebanyak 31\% menyatakan melarang, 40\% membolehkan, dan 29\% membiarkan pembelajaran membaca, menulis, dan berhitung di TK dan RA.

Berdasarkan kategori, data di atas dapat diartikan bahwa sebagian besar kepala sekolah dan guru tidak pernah mendapat instruksi atau perintah dari Dinas Pendidikan/ Kementrian Agama Kecamatan Cipanas, Kecamatan Pacet, dan Sukaresmi Kab. Cianjur untuk mewajibkan pembelajaran membaca, menulis, dan berhitung di TK dan RA. Akan tetapi sikap tidak mewajibkan tersebut dipahami dengan berbeda oleh kepala sekolah dan guru, yaitu menganggap dilarang, dibolehkan dan dibiarkan. Hal ini berarti tidak ada kesamaan pendapat baik kepala sekolah ataupun guru tentang pembelajaran membaca, menulis, dan berhitung di TK dan RA. Sebagian menganggap tidak diwajibkan sebagai larangan, sebagian menganggap membolehkan, dan yang lain mengartikannya sebagai sikap membiarkan. Perbedaan pendapat di kalangan kepala sekolah dan guru tentang pembelajaran membaca, menulis, dan berhitung di TK dan RA dapat menimbulkan kebingungan di masyarakat terutama kalangan orangtua siswa. Orangtua yang menganggap baca, tulis, hitung penting bagi anak mereka akan memilih TK atau RA yang menyelenggarakan pembelajaran membaca, menulis, dan berhitung; orangtua yang tidak menganggap penting, maka akan memilih TK atau RA yang tidak membelajarkan baca, tulis, hitung; atau sebagian orangtua siswa menyerahkan sepenuhnya kepada pihak sekolah.

Tabel 1

Kebijakan Dinas Pendidikan dan Kementrian Agama Kecamatan Cipanas

Pacet, dan Sukaresmi Kabupaten Cianjur tidak mewajibkan

pembelajaran prabaca, pratulis, dan prahitung

$(52,5 \%$ dari $\mathrm{N}=80)$, dengan rincian sebagai berikut.

\begin{tabular}{|c|l|c|}
\hline No. & $\begin{array}{l}\text { Sikap Dinas Pendidikan } \\
\text { dan Kementerian Agama } \\
\text { terhadap pembelajaran } \\
\text { m e m b a c a, m e n u I i s, } \\
\text { berhitung di TK dan RA. }\end{array}$ & Prosentase \\
\hline 1. & Melarang & 31 \\
\hline 2. & Membolehkan & 40 \\
\hline 3. & Membiarkan & 31 \\
\hline
\end{tabular}


Olah data menggunakan prosentase atas pertanyaan penelitian kedua, menghasilkan sebagai berikut: (a) sebanyak $87,5 \%$ responden menyatakan bahwa TK dan RA di sekitar sekolah mereka memberikan pembelajaran membaca, menulis, berhitung kepada siswanya; (b) hanya 36,25\% sekolah dasar di sekitar TK dan RA mereka memberlakukan anak sudah bisa baca, tulis, hitung sebagai syarat masuk; (c) sebanyak 80\% menyatakan TK dan RA memberikan pembelajaran membaca, menulis, dan berhitung kepada siswanya; (d) $80 \% 77,5 \%$ menyatakan di TK dan RA tempat mereka bekerja turut memberikan pembelajaran membaca, menulis, dan berhitung; (e) $77,5 \%$ menyatakan kepala sekolah dan guru di TK dan RA mereka diberikan pembelajaran membaca, menulis, dan berhitung; (f) $82,5 \%$ menyatakan alasan mereka memberikan pembelajaran membaca, menulis, dan berhitung karena tuntutan orangtua siswa;

(g) sebanyak 52,5\% responden menyatakan bahwa pembelajaran membaca, menulis, dan berhitung dilaksanakan di luar jam pembelajaran biasa; (h) sebanyak 72,5\% responben menyatakan bahwa pembelajaran membaca, menulis, dan berhitung berbentuk privat baca, tulis, hitung; (i) $86,25 \%$ responden menyatakan bahwa orangtua siswa setuju diadakan privat baca, tulis, hitung;

(j) $82,5 \%$ responden menyatakan bahwa mereka membuat perencanaan sebelum melaksanakan pembelajaran membaca, menulis, dan berhitung; (k) sebanyak 62,5\% responden menyatakan bahwa mereka menggunakan media dalam memberikan pembelajaran membaca, menulis, dan berhitung; (I) sebanyak 82,5\% menyatakan bahwa mereka menggunakan alat peraga dalam pembelajaran membaca, menulis, dan berhitung; ( $\mathrm{m}$ ) sebanyak $82,5 \%$ responden menyatakan bahwa mereka melakukan evaluasi terhadap keberhasilan pembelajaran membaca, menulis, dan berhitung.

Data di atas jika diterjemahkan lebih jauh menunjukkan bahwa (1) sebagian besar TK dan RA di sekitar sekolah mereka memberikan pembelajaran membaca, menulis, berhitung kepada siswanya; (2) sebagai kecil sekolah dasar di sekitar TK dan RA mereka memberlakukan anak sudah bisa baca, tulis, hitung sebagai syarat masuk; (3) sebagian besar TK dan RA memberikan pembelajaran membaca, menulis, dan berhitung kepada siswanya; (4) sebagian besar di TK dan RA tempat mereka bekerja turut memberikan pembelajaran membaca, menulis, dan berhitung; (5) sebagian besar kepala sekolah dan guru di TK dan RA mereka memberikan pembelajaran membaca, menulis, dan berhitung; (6) sebagian besar menyatakan alasan kepala seklolah dan guru memberikan pembelajaran membaca, menulis, dan berhitung karena tuntutan orangtua siswa; (7) sebagian besar pembelajaran membaca, menulis, dan berhitung dilaksanakan di luar jam pembelajaran biasa; (8) sebagian besar kepala sekolah dan guru menyatakan bahwa pembelajaran membaca, menulis, dan berhitung berbentuk privat baca, tulis, hitung; (9) sebagian besar orangtua siswa setuju diadakan privat baca, tulis, hitung;

(10) sebagian besar kepala sekolah dan guru membuat perencanaan sebelum melaksanakan pembelajaran membaca, menulis, dan berhitung; (11) sebagian besar kepala sekolah dan guru menggunakan media dalam memberikan pembelajaran membaca, menulis, dan berhitung; (12) sebagian besar kepala sekolah dan guru menggunakan alat peraga dalam pembelajaran membaca, menulis, dan berhitung; (13) sebagian besar kepala sekolah dan guru melakukan evaluasi terhadap keberhasilan pembelajaran membaca, menulis, dan berhitung.

Berdasarkan hasil penelitian di atas dapat disimpulkan, pertama adalah wajar jika terjadi prokontra tentang pembelajaran membaca, menulis, dan berhitung di taman kanak-kanak dan Raudhatul Athfal; mengingat baik kepala sekolah maupun guru TK dan RA yang berada di wilayah Kecamatan Cipanas Pacet, dan Sukaresmi Kabupaten Cianjur berbeda pendapat, ada yang setuju dan tidak, meskipun jumlah yang setuju lebih banyak.

S i k a p prokontram a s y a ra k $\mathrm{t}$ (pemerintah, penyelenggara Paud, kepala sekolah, guru, dan orangtua siswa) mengenai pembelajaran membaca, menulis, dan berhitung sejalan dengan pendapat para ahli PAUD yang berbeda-beda. Banyak ahli yang tidak merekomendasikan atau bahkan melarang pembelajaran membaca, menulis, dan berhitung bagi anak usia dini, meskipun untuk kelompok B (usia 5-6 tahun), akan tetapi tidak sedikit ahli mendukung dan menganggap penting. Morrison (2012) menyebut bahwa pengalaman akademik seperti baca-tulis, dan membaca, matematika sangat penting selain ilmu pengetahuan alam, ilmu sosial, dan seni. Havighurst (1972), menganggap penting mempersiapkan keterampilan-keterampilan dasar untuk membaca, menulis, dan berhitung pada akhir masa kanak-kanak. 
Hal senada disampaikan Hurlock (1980) bahwa penting untuk dikembangkan berbagai keterampilan dasar, seperti membaca, menulis, berhitung, dan pengembangan sikap di akhir masa kanak-kanak, seperti melalui kegiatan melihat gambar, majalah, buku dan mendengar dongeng-dongeng atau cerita. Dalam pendidikan Montessori pembelajaran membaca dan menulis juga masuk dalam salah satu kegiatan dalam pendidikannya (academic materials), di samping pendidikan gerak (practical life) dan latihan panca indera (sensory materials).

Ke d u a, a l a s a n d i b e ri k a n $\mathrm{n}$ y a pembelajaran membaca, menulis, dan berhitung di TK dan RA karena pemintaan orangtua siswa.

Keluarga merupakan salah satu faktor penentu keberhasilan pendidikan anak. Pada masa- masa awal kehidupan seorang anak, peran orangtua terutama ibu sangat besar. Hampir seluruh kehidupan anak, termasuk pendidikannya diatur oleh ibu. Setiap ibu akan memberikan terbaik bagi masa depan anakanaknya. Pembelajaran membaca, menulis, dan berhitung oleh sebagaian besar orangtua dianggap sebagai pengetahuan dasar untuk memahami ilmu pengetahuan. Di sekolah dasar yang bersifat penguasaan akademik, minat dan kemampuan baca, tulis, dan hitung sangat penting. Tidak salah jika para orangtua meminta agar TK atau RA memberikan pembelajaran membaca, menulis, dan berhitung bagi anak mereka. Sejalan dengan sikap orangtua tersebut, hasil studi Durkin dan Sternberg (Dhieni, dkk, 2008) menganggap penting dan menyatakan tidak ada efek negatif pada anak- anak membaca dini, bahkan anak-anak yang telah belajar membaca sebelum masuk sekolah dasar cenderung lebih maju di sekolah daripada yang belum pernah membaca sejak dini. Belajar membaca juga akan memenuhi keingintahuan anak, menciptakan suasana akrab di antara anak, membuat anak terkesan, dan dapat mempelajari sesuatu lebih mudah dan cepat. Pembelajaran membaca, menulis, dan berhitung bagi anak usia dini harus didukung dengan metode atau cara yang tepat dan sesuai perkembangan anak. Kenyataan di lapangan menunjukkan banyak TK atau RA memberikan pembelajaran membaca, menulis, dan berhitung tidak sesuai karakteristik perkembangan anak dan salah tujuan, seperti dengan cara memaksa dan mengejar anak cepat bisa. Para orangtua harus bisa memilih sekolah yang benar-benar berorientasi kebutuhan perkembangan anak, yang mengutamakan upaya menumbuhkembangkan minat dan kegemaran anak terhadap bahan bacaan, seperti buku; bukan sekedar bisa baca (Masnipal, 2013, 2015).

Ketiga, hasil penelitian menunjukkan bahwa pembelajaran membaca, menulis, dan berhitung di TK dan RA diberikan di luar jam pelajaran dan berbentuk privat. Proses pembelajaran anak usia dini harus melibatkan seluruh aspek perkembangan (kognitif, fisik-motorik, bahasa, emosi, dan sosial). Pembelajaran prabaca, pratulis, dan prahitung tidak boleh terpisah atau berada di luar dari proses pembelajaran. Mengenal huruf misalnya adalah bagian dari pengembangan bahasa, menulis bagian dari motorik halus, dan berhitung bagian dari kognitif. Oleh karena proses pembelajaran bagi anak usia dini bersifat bermain aktif maka akan bertentangan dengan cara-cara privat, dimana anak hanya berhadapan dengan guru dalam posisi pasif.

Keempat, dalam membelajarkan membaca, menulis, dan berhitung guru TK dan RA membuat perencanaan dan dilaksanakan dengan menggunakan alat peraga dan media pembelajaran, serta melakukan evaluasi. Oleh karena pembelajaran prabaca, pratulis, dan prahitung bagian dari suatu proses pembelajaran, maka seharusnya materi dan rencana kegiatannya masuk dalam rencana pelaksanaan pembelajaran harian (RPPH) dan juga bagian dari aspek yang dievaluasi pada akhir pembelajaran. Penggunaan alat peraga dan media pembelajaran sangat penting dalam pendidikan anak usia dini. Media dan alat peraga akan membantu anak menyukai pembelajaran, selain sebagai alat bermain. Berbagai penelitian menunjukkan bahwa penggunaan media dapat mempertinggi kualitas pembelajaran sehingga mampu meningkatkan kemampuan belajar siswa (Sadiman, 2010; Arsyad, 2011; Zaman \& Eliyawati, 2010).

\section{Kesimpulan}

Dari hasil penelitian dapat disimpulkan bahwa: Pertama, Dinas Pendidikan atau Kementrian Agama Kecamatan Cipanas, Kecamatan Pacet, dan Sukaresmi Kab. Cianjur tidak mewajibkan untuk memberikan pembelajaran prabaca, pratulis, dan prahitung di TK dan RA. Sikap tersebut menimbulkan pemahaman yang berbeda di kalangan kepala sekolah dan guru, yaitu menganggap 
dilarang, dibolehkan dan dibiarkan. Kedua, terjadi prokontra tentang pembelajaran membaca, menulis, dan berhitung di TK dan RA, sebagian besar melaksanakan dan sebagian yang lain tidak melaksanakan. Ketiga, pemberian kegiatan prabaca, pratulis, dan prahitung di TK dan RA lebih didasarkan atas pemintaan orangtua siswa. Keempat, kegiatan prabaca, pratulis, dan prahitung di TK dan RA dilaksanakan di luar jam pelajaran dan berbentuk privat. Kelima, dalam melaksanakan kegiatan prabaca, pratulis, dan prahitung di TK dan RA, guru terlebih dahulu membuat perencanaan dan melakukan evaluasi pada akhir pembelajaran dan dalam pelaksanaan guru menggunakan media dan alat peraga.

\section{Daftar Pustaka}

Arsyad, A. (2011). Media Pembelajaran. Jakarta: Rajawali Press.

Hurlock, E. B. (1980). Psikologi Perkembangan, Suatu Pendekatan Sepanjang Rentang Kehidupan (Terjemahan edisi ke-5). Jakarta: Erlangga.
Masnipal. (2013). Siap menjadi Guru dan Pengelola Paud Profesional. Jakarta: PT. Elexmedia Komputindo-Gramedia.

----- (2015), Dasar-Dasar Pendidikan Anak Usia Dini; Panduan bagi Mahasiswa Calon Guru \&Pengelola Paud Profesional. Bandung: PG PAUD UNISBA (tidak diterbitkan).

Morrison, G. S. (1988). Early Childhood Education Today. Columbus, Ohio: Merrill Publishing Company.

(2008).Fundamentals of Early Childhood Education, 5th Edition. New Jersey: Pearson Education, Inc.

Majelis Luhur Taman Siswa. (1977). Karya Ki Hajar Dewantara, Bagian Pertama: Pendidikan; cetakan kedua. Yogyakarta: Majelis Luhur Taman Siswa.

Sadiman, A. S, dkk. (2010). Media Pendidikan. Jakarta: Rajawali Press.

Zaman, B \& Cucu, E. (2010) . Media Pembelajaran Anak usia Dini. Jakarta: Universitas Pendidikan Indonesia. 